\title{
A Nutrient Combination That Can Affect Yield of Olitorius Jute
}

\author{
Md Saheb Ali ${ }^{1}$, Md Marfudul Hoque ${ }^{1,2}$, Md Abdul Alim ${ }^{1}$, Md Mahbubul Islam ${ }^{1,3, ~ * ~}$ \\ ${ }^{1}$ Agronomy Division, Bangladesh Jute Research Institute, Dhaka, Bangladesh \\ ${ }^{2}$ Department of Agriculture Extension Kaptai, Rangamati, Bangladesh \\ ${ }^{3}$ PTC Division, Bangladesh Jute Research Institute, Dhaka, Bangladesh
}

Email address:

mahbub_agronomy@yahoo.com (Md M. Islam)

${ }^{*}$ Corresponding author

\section{To cite this article:}

Md Saheb Ali, Md Marfudul Hoque, Md Abdul Alim, Md Mahbubul Islam. A Nutrient Combination That Can Affect Yield of Olitorius Jute. Plant. Vol. 7, No. 3, 2019, pp. 42-46. doi: 10.11648/j.plant.20190703.13

Received: July 26, 2019; Accepted: August 19, 2019; Published: August 29, 2019

\begin{abstract}
Mineral fertilizer use is expanding in Jute growing countries to satisfy fiber demands. Fertilizer consumers are being asked to improve fertilizer use efficiency through better management in their fields to provide a healthy economy. Following the thought a field experiment was established to determine the influence of mineral fertilizer (NPKS) on growth and yield of the advanced $C$. olitorious breeding line of O-043-7-9. We selected three different locations under Bangladesh Jute Research Institute to examine jute crop response to optimum fertilizer combination and the yield variability by 10 different nutrient combinations. Because of the essentiality of N, P, K, and S fertilizer combination on Jute fibre production and their effects on its growth were studied. The lower levels of N, P, K and S were zero applications in specific treatments. N, P, K and $\mathrm{S}$ were positively correlated with yield level. Over time, the simple effect of $\mathrm{N}$ exhibited an increased positive trend only when applied limited to $100 \mathrm{~kg} / \mathrm{ha}$, while simple effects of $\mathrm{P}$ and $\mathrm{K}$ increased sharply at the rate 10 and $30 \mathrm{~kg} / \mathrm{ha}$ respectively. The zero fertilizer treatment yielded decline for each mineral in specific treatment in the trial. Fertilizer N, P, K and S were utilized more efficiently in fully balanced combination. After the findings from three different locations for growth, yield and agronomic characteristics, we can draw the conclusion that the combination dose of $\mathrm{N}_{100} \mathrm{P}_{10} \mathrm{~K}_{30} \mathrm{~S}_{15} \mathrm{Kg} / \mathrm{ha}$ may need to be applied for breeding line O-043-7-9 cultivation in Bangladesh.
\end{abstract}

Keywords: Yield, Jute, Nitrogen, Potassium, Phosphorus, Sulfur

\section{Introduction}

Among the total jute fibre production in the world, ninety two percent produced in Bangladesh and India. Raw jute signifies fibre produced from, Corchorus capsularis, Corchorus olitorius, Hibiscus sabdariffa and Hibiscus cannabinus. Renowned jute growing areas in Bangladesh are Faridpur, Jessore, Manikganj, Kishoregan, Mymensingh and Rangpur regions. Corchorus olitorius is one of the most popular fibre crops in every districts of Bangladesh. Corchorus olitorius is mainly known for its fibre product, jute and for its leafy vegetables [1]. Several species of Corchorus are used as vegetable, of which Corchorus olitorius is most frequently cultivated. C. olitorius is consumed as a healthy vegetable in Japan, because it contains abundant carotenoids, vitamin B1, B2, C and E, and minerals. On the other hand, accidental death of cattle has occurred when the cattle were feed with vegetation containing the seeds, because the seeds contain cardiac glycoside [2]. The dark-green leaves of $C$. olitirius have varying proportion of $\mathrm{Ca}, \mathrm{Fe}$, -carotene, vitamin $\mathrm{C}$, fibreand protein required for health $[1,3]$. Nutrition is an important aspectof Jute production system and this includes adequate supply of essential nutrients like nitrogen, phosphorus, potassium, sulfur etc to the plant.

The availability of these nutrients to plant contributes a lot to its growth and yield. Therefore adequate amount of nutrients need to be supplied to plant at the right quantity and also at the right time to favour both growth and yield. NPKS have influence on the growth and yield of fibre crops [4-40]. Fertilizer studies showed positive responses of Corchorus 
olitorius to nitrogen [41]. Phosphorus is important in root development and helps hasten maturity of the fruit. Soils require extraneous inputs of phosphorus for optimum Corchorus olitorius growth [42]. The role of nitrogen and phosphorus in crop fertilization, leading to increased absorption of elements can be attributed to increase top growth particularly as a result of nitrogen absorption [43]. Similarly, application of any essential element should have a marked effect on yield if the soils were deficient in the element. Therefore, it is necessary to determine the growth and yield performance of the advance olitorius lineO-043-7-9 by nutrient combination.

\section{Methods}

The experiment was conducted at three locations of Bangladesh Jute Research Institute to determine the nutritional requirement for optimum growth and yield of the advanced $C$. olitorious breeding line of O-043-7-9. The experiment was laid outin randomized complete block design with three replications. A total of 10 treatment combinations along with a control were distributed randomly in each equal plot as one replication. Each replication was divided into 10unit plots. At the time of final land preparation, the land was well prepared and fertilizers were applied as per treatment (Table 1). NPKS fertilizers were applied in the form of urea, TSP, MAP and gypsum respectively. Half of urea was applied at sowing and the rest half was top dressed at45 days after sowing while all other fertilizers were applied at the time of sowing. At harvesting time, ten plants were selected at random from each plot and tagged in the field to make a note of yield and yield contributing parameters.

Table 1. Treatment combinations (NPKS in Kg/ha).

\begin{tabular}{ll}
\hline T1: N0P10K30S20 & T6: N100P15K30S20 \\
T2: N75P10K30S20 & T7: N100P10K0S20 \\
T3: N100P10K30S20 & T8: N100P10K45S20 \\
T4: N125P10K30S20 & T9: N100P10K30S0 \\
T5: N100P0K30S20 & T10: N100P10K30S15 \\
\hline
\end{tabular}

\section{Results and Discussions}

Our research findings showed that among the ten nutrient combinations of chemical fertilizer, nutrient combination for treatment $\mathrm{T}_{10}$ performed best for the advanced breeding line O-043-7-9 yield and yield influencing factors. The plant growth and yield were affected by $\mathrm{N}$ levels over the control. Nitrogen@100 kg/ha treatment $\left(\mathrm{T}_{10}\right)$ produced significant highest fibre yield. But highest dose of N $125 \mathrm{~kg} /$ ha showed significantly lower yield than the dose N $100 \mathrm{~kg} / \mathrm{ha}$. The growth indicator i.e. plant height and base diameter were found significantly highest by $\mathrm{N} 100 \mathrm{~kg} / \mathrm{ha}\left(\mathrm{T}_{10}\right)$ that was identical with the treatments $\mathrm{T}_{3}, \mathrm{~T}_{4}, \mathrm{~T}_{6}, \mathrm{~T}_{7}$ and $\mathrm{T}_{8}$. From the results, it was observed that $100 \mathrm{~kg} \mathrm{~N} /$ ha may be an adequate amount for fibre production for the advance breeding line O043-7-9. The different results noticed that application of higher dose of fertilizer consequenced on growth and yield of fibre production of the advance olitorius line O-043-7-9 (Figures 1-4).

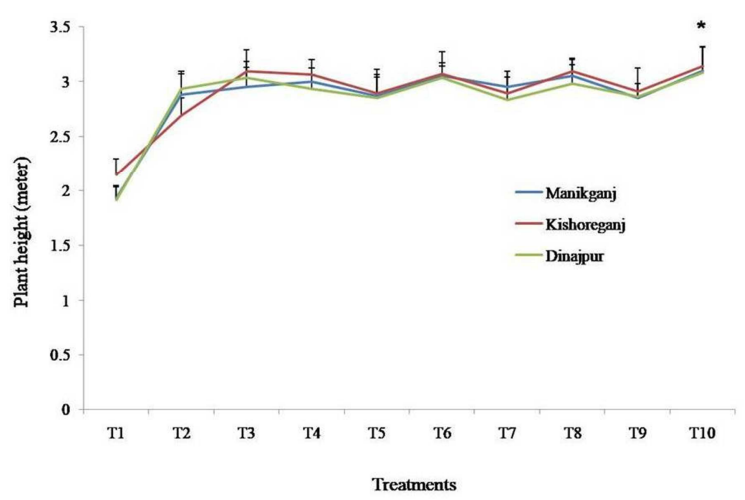

Figure 1. Plant height of olitorius breeding line O-043-7-9 using different chemical fertilizer treatments. Each datum was calculated from three independent experiments. The results are expressed as the mean \pm S.E.M. ${ }^{*} p<0.05$ significance by the Student's t-test.

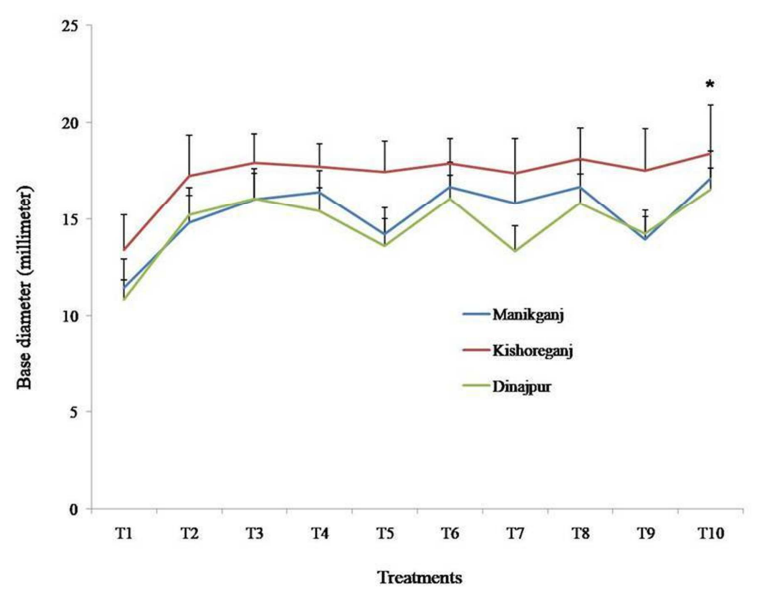

Figure 2. Base diameter of olitorius breeding line O-043-7-9 using different chemical fertilizer treatments. Each datum was calculated from three independent experiments. The results are expressed as the mean \pm S.E.M. $*_{p}<0.05$ significance by the Student's t-test.

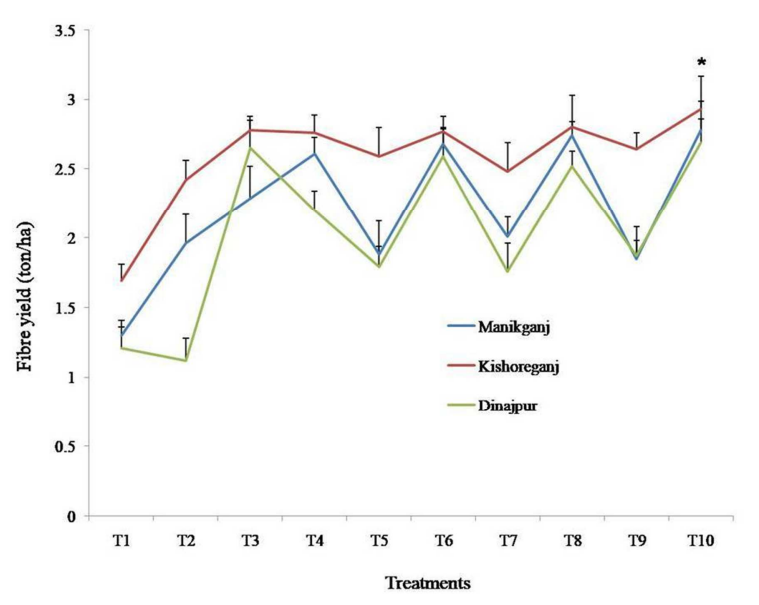

Figure 3. Fibre yield of olitorius breeding line O-043-7-9 using different chemical fertilizer treatments. Each datum was calculated from three independent experiments. The results are expressed as the mean \pm S.E.M. ${ }^{*} p<0.05$ significance by the Student's $t$-test. 


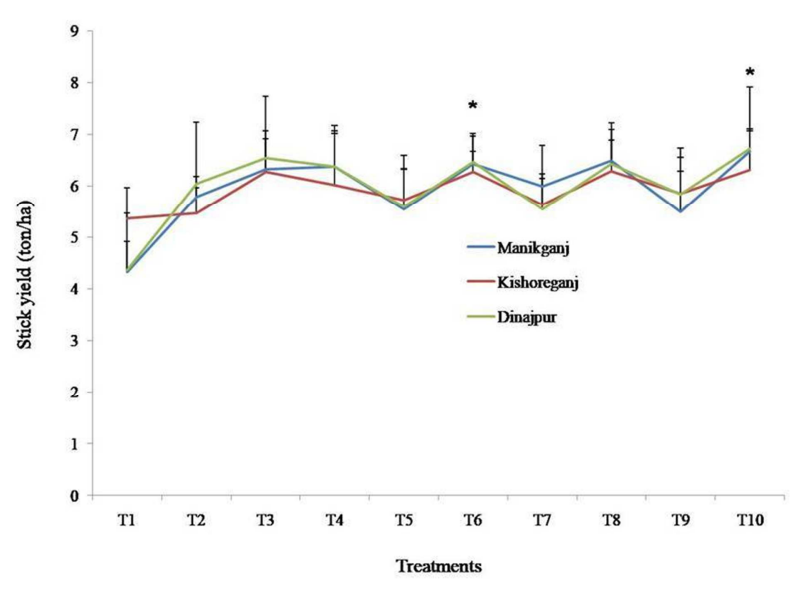

Figure 4. Stick yield of olitorius breeding line O-043-7-9 using different chemical fertilizer treatments. Each datum was calculated from three independent experiments. The results are expressed as the mean \pm S.E.M. ${ }^{*} p<0.05$ significance by the Student's t-test.

The yield and yield influencing factors of O-043-7-9 were affected due to addition of different phosphorus levels. The dose of P $10 \mathrm{~kg} / \mathrm{ha}$ contributed maximum yield of fibre $(2.78 \mathrm{t} / \mathrm{ha})$ and stick (6.67 t/ha) at Manikganj (Figure $3 \&$ Figure 4). Results also explored that the longest plant $(3.14 \mathrm{~m})$ and base diameter $(18.39 \mathrm{~mm})$ were found significantly higher with $10 \mathrm{~kg} \mathrm{P} / \mathrm{ha}$ at Kishoreganj (Figure 1 \& Figure 2).

To observe potassium $(\mathrm{K})$ requirement, there was applied three rates of $\mathrm{K}$, such as 0,30 , and $45 \mathrm{~kg} / \mathrm{ha}$. The rate $30 \mathrm{~kg}$ $\mathrm{K} /$ ha gave the statistically highest plant height $(3.08 \mathrm{~m})$, base diameter $(16.56 \mathrm{~mm})$ fibre yield $(2.69 \mathrm{t} / \mathrm{ha})$ and stick yield $(6.72 \mathrm{t} / \mathrm{ha})$ at Dinajpur. But the supreme rate of $\mathrm{K} 45 \mathrm{~kg} / \mathrm{ha}$ yielded lower fibre yield (2.52 t/ha) compare to $\mathrm{K} 30 \mathrm{~kg} / \mathrm{ha}$ (Figure 3). Study noticed that the advance olitorus breeding line $\mathrm{O}-043-7-9$, needs $\mathrm{K} 30 \mathrm{~kg} / \mathrm{ha}$ to produce maximum yield.

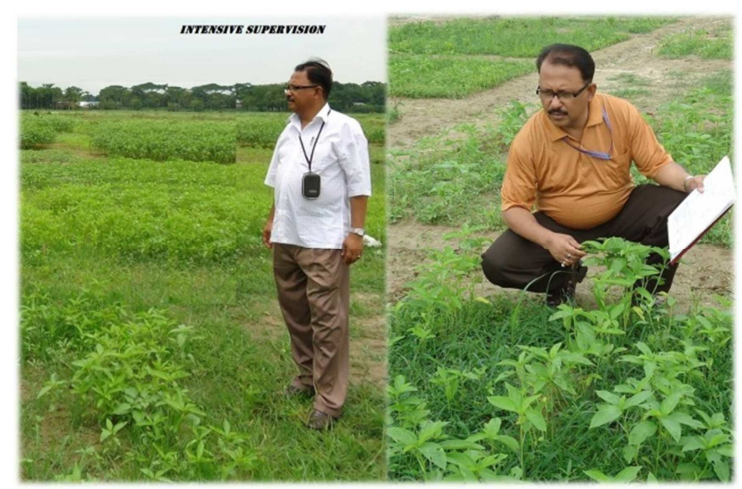

Figure 5. Intensive supervision signifying in experimental field for good agronomic practices by Dr. Md. Mahbubul Islam, Chief Scientific Officer \& Head of Agronomy Division, Bangladesh Jute Research Institute, Manik Mia Avenue, Dhaka-1207, Bangladesh.

Highest plant height $(3.14 \mathrm{~m})$, base diameter $(18.39 \mathrm{~mm})$ fibre yield (2.93t/ha) and stick yield (6.31t/ha) were observed with $15 \mathrm{~kg} \mathrm{~S} /$ ha (Figures 1-4). Results showed that the combined dose of NPK and S 100-10-30-15 kg/ha may be a suitable dose for the cultivation of advance breeding line $\mathrm{O}$ -
043-7-9. The nutrient combination and their ratio is one of the key factors for olitorus breeding line O-043-7-9 production that is supported by previous report [4, 32, 33]. This outcome is owing to competent direction and time to time suggestion about experimental events (Figure 5)

\section{Conclusion}

The overall treatments had significant positive impact over nitrogen control $\left(\mathrm{T}_{1}\right)$ on growth and yield and effect of combined fertilizers on them were explained. The most important parameter, fibre yield $(2.93 \mathrm{t} / \mathrm{ha})$ and stick yield (6.72 t/ha), were recorded highest with $\mathrm{T}_{10}: \mathrm{N}_{100} \mathrm{P}_{10} \mathrm{~K}_{30} \mathrm{~S}_{15}$ treatment. Considering all these aspects, specially yield, $\mathrm{T}_{10}: \mathrm{N}_{100} \mathrm{P}_{10} \mathrm{~K}_{30} \mathrm{~S}_{15} \mathrm{~kg} /$ ha treatment seems to be the best combination for the yield potential of the advance breeding line 0-043-7-9.

\section{Author Contributions}

All authors contributed equally.

\section{Conflict of Interest Statement}

The authors declare that they have no competing interests.

\section{Acknowledgements}

Thanks to Jute Research Stations of BJRI and Ministry of Agriculture, Bangladesh is acknowledged.

\section{References}

[1] Schippers RR (2000). African indegenous vegetables: An overview of the cultivated species. University of Greenwich. England 193-205.

[2] Matsufuji H, Sakai S, Chino M, Goda Y, Toyoda M, et al. (2001). Relationship between cardiac glycoside contents and colour of Corchorus olitorius seeds. J Health Sci 47: 89-93.

[3] Adebanjo A, Shopeju E (1993). Sources of mycoflora associated with some sundried vegetables in storage. Int Biodeterior Biodegrad 31: 255-263.

[4] Ali MS, Gani MN, Islam MM (2017). Efficiency of BJRI Kenaf-4 Yield Under Different Fertilizer Levels. A J Agric For 5: 145-149.

[5] Ali MS, Hossen M, Ahmed B, Gani MN, Islam MM (2017). Jute Seed Yield Response to Irrigation and Nitrogen Fertilization in Field-Grown Environment. Int J Biol Environ Eng 2: 9-13.

[6] Akanbi WB, Olaniyan AB, Togun AO, Ilupeju AEO, Olaniran OA (2009). The effect of organic and inorganic fertilizer on growth, calyx yield andquality of Roselle (Hibiscus sabdariffa L.). Am Eurasian J Sustain Agric3: 652-657.

[7] Sakimin SZ, Patrie SS, Juraimi AS, Alam MA, Aslani F (2017). Growth performance of roselle (hibiscus sabdariffa L.) in response to oil palmby-product media and controlled release fertilizer. Bangladesh J Bot46: 427-431. 
[8] Sajid M, Rab A, Jan I, Iqbal A, Shah F, et al. (2017). Response of various growth parameters of roselle (Hibiscus sabdariffa L.) to organic and inorganic phosphorus. Fresenius environmental bulletin 26: 878-884.

[9] Atta A, Diallo AB, Bakasso Y, Sarr B, Saadou M, et al. (2010). Microelement contents of roselle (Hibiscus sabdariffa L.) at different growth stages. Afr J Food Agric Nutr Dev 10.

[10] Haruna IM, Maunde SM, Yahuza S (2011). Growth and calyx yield ofRoselle (HIBISCUS SABDARIFFA L.) as affected by poultry manureand nitrogen fertilizer rates in the southern guinea savanna of nigeria. Can J Pure Appl Sci 5: 1345-1348.

[11] Javadzadeh SM, Pour MS (2017). Morpho-agronomic characteristicsof two Roselle varieties (Hibiscus sabdariffa L.) in tropical Iransher. IntJ Adv Res Biol Sci 4: 99-104.

[12] Pushpa K, Murthy NK, Murthy RK, Sharanappa, Vishwanath AP (2016). Nutrient uptake in mesta (Hibiscus cannabinus) as influencedby varieties, spacing and nutrient sources. Environ Ecol 34: 489-493.

[13] Khalil SE, Yousef RM (2014). Study the effect of irrigation water regimeand fertilizers on growth, yield and some fruit quality of Hibiscussabdariffa L. Int J Adv Res 2: 738-750.

[14] Ibrahim EB, Abdalla AWH, Ibrahim EA, Naim AME (2013). Interrelationships between yield and it components in some Roselle (Hibiscus sabdariffa L.) Genotypes. World J Agric Res 1: 114-118.

[15] Dahmardeh M (2012). Effect of mineral and organic fertilizers onthe growth and calyx yield of roselle (Hibiscus sabdariffa L.). Afr JBiotechnol 11: 10899-10902.

[16] Musa A, Ogbadoyi EO (2011). Effect of Nitrogen Fertilizer on the Levelsof Some Nutrients, Anti-Nutrients and Toxic Substances in Hibiscussabdariffa. Asian J Crop Sci 4: 103-112.

[17] Abbas MK, Ali AS (2011). Effect of Foliar Application of NPK on someGrowth Characters of Two Cultivars of Roselle (Hibiscus sabdariffa L.). Am J Plant Physiol 6: 220-227.

[18] Atta S, Seyni HH, Bakasso Y, Sarr B, Lona I, et al. (2011). Yieldcharacter variability in Roselle (Hibiscus sabdariffa L.). Afr J Agric Res6: 1371-1377.

[19] Gad N (2011). Productivity of Roselle (Hibiscus sabdariffa L.) Plant asaffected by Cobalt and Organic Fertilizers. J Appl Sci Res 7: 1785-1792.

[20] Haruna IM, Ibrahim HY, Rahman SA (2011). The yield and profitabilityof roselle (Hibiscus sabdariffa L.) at varying poultry manure andnitrogen fertilizer rates in the southern guinea savanna of Nigeria. JAgric Technol 7: 605-609.

[21] Ahmed YM, Shalaby EA, Shanan NT (2011). The use of organic andinorganic cultures in improving vegetative growth, yield charactersand antioxidant activity of roselle plants (Hibiscus sabdariffa L.). Afr JBiotechnol 10: 1988-1996.

[22] Oyewole CI, Mera M (2010). Response of roselle (Hibiscus sabdariffaL.) to rates of inorganic and farmyard fertilizers in the Sudan savannaecological zone of Nigeria. Afr J Agric Res 5: $2305-2309$

[23] Atta S, Sarr B, Bakasso Y, Diallo AB, Lona I, et al. (2010). Roselle (Hibiscus Sabdariffa L.) yield and yield components in response tonitrogen fertilization in Niger. Indian J Agric Res 44: 96-103.
[24] Haruna IM, Ibrahim H, Rahman SA (2009). The yield and profitability ofRoselle (Hibiscus sabdariffa L.) at varying poultry manure and nitrogenfertilizer rates in the Southern Guinea Savanna of Nigeria. Electronic JEnviron Agric Food Chem 8: 1136-1139.

[25] Hassan FAS (2009). Response of Hibiscus sabdariffa L. plant to somebiofertilization treatments. Ann Agric Sci 54: 437-446.

[26] Alam AKMM, Khandker S, Gani MN, Ahmed SA (2000). Uptake addition and balance of nutrients under integrated fertilizer management in jute based cropping patterns. B J Sci Tech 2: 147-153.

[27] Sarker AK, Bandopaddhay PK (2000). Effect of potassium, boron andcrop age on the yield and quality of white jute (Corchorus capsularis). Indian Agric 26: 212-216.

[28] Das K, Guha B, Pathak D (1996). Response of Capsularis jute topotassium fertilization. Ann Agric Res 17: 188-189.

[29] Sarkar SK, Ghosh RK, Sounda G, Maitra S, Rux DK, et al. (1997). Effectof levels of nitrogen, potassium and soil moisture tension on growth, nutrient uptake and water use efficiency of jute. J Interacademia 1: 183-188.

[30] Zheng ZH, Huang YX, Peng XJ (1984). Effects of additional Kapplication to jute. China's Fiber Crops 2: 14-15.

[31] Chew WY, Malek MAA, Ramli K (1982). Nitrogen and potassiumfertilization of congo jute (Urena lobata) and kenaf (Hibiscuscannabinus) on Malaysian peat. MARDI-Res. Bulletin 10: 317-322.

[32] Islam MM, Alam ATMM (2012). Agronomic Research and Advancementin Jute Crop in Bangladesh, (Sub-Theme Paper). Souvenir, $11^{\text {th }}$ Conference on Advances in Agronomic Research under Changing Environment in Bangladesh. At Bangladesh Agricultural Research Institute, Joydebpur, Gazipur-1701, Bangladesh. 101.

[33] Islam MM, Rahman MM (2008). Hand book on agricultural Technologies of Jute, Kenaf and Mesta crops. Bangladesh Jute Research Institute, Manikmia Avenue, Dhaka-1207, Bangladesh.

[34] Islam MM (2013). Jute of Bangladesh: It's contribution to environment and challenges. The Reflector, Reflecting the issues and development in societies and states. Md. Eanyet Ullah, Bangladesh 2: 8-10.

[35] Islam M M (2019). Varietal Advances of Jute, Kenaf and Mesta crops in Bangladesh: A review. Int J Bioorganic Chem, 4 (1), 24-41.

[36] Gani MN, Ali MS (2018). Md. Mahbubul Islam. Nutritional Requirements of Newly Released Tossa Jute MG-1. American Journal of Food, Nutrition and Health, 3 (2), 31-34.

[37] Islam MM, Ali MS (2017). Economic Importance of Jute in Bangladesh: Production, Research Achievements and Diversification. International Journal of Economic Theory and Application, 4 (6), 45-57.

[38] Ali MS, Gani MN, Islam MM (2017). Nutrient Management on Growth and Yield of BJRI Tossa Pat 6. Nutr Food Technol Open Access, 3 (3).

[39] Ali MS, Hoque MM, Gani MN, Islam MM (2017). Variation in Inorganic Fertilizer Is an Important Regulator of Yield Potential in BJRI Mesta-3. American Journal of Environmental Engineering and Science, 4 (6), 78-84. 
[40] Gani MN, Ali MS, Islam MM (2017). Nutrient Requirement of NPK\&S on Advance Capsularis Breeding Line BJC-5105. Biosystems Engineering, 2 (5), 44-47.

[41] NIHORT (1986). Advances in fruit and vegetable research at NIHORT. A commemorative publication, Ibadan, Nigeria.

[42] Zapata F, Axman H (1995). 32P Isotopic techniques for evaluating nthe agronomy effectiveness of rock phosphate materials. Fertilizer Research 41: 189-195.

[43] Olaniyi JO (2000). Growth, seed yield and nutrient composition of egusimelon cultivars as affected by NPK 1515-15 fertilization. Journal of Agricultural Biotechnology and Environment 2: 11-16. 